\title{
Application of Rainwater Harvesting Technology to Supply Sustainable Domestic Water
}

\author{
Joleha* \\ Civil Engineering Department \\ Universitas Riau \\ Indonesia
}

\author{
Aras Mulyadi \\ Postgraduate Doctor of Environmental \\ Science Program \\ Universitas Riau \\ Indonesia \\ Imam Suprayogi \\ Postgraduate Doctor of Environmental \\ Science Program \\ Universitas Riau \\ Indonesia
}

\author{
Wawan \\ Postgraduate Doctor of Environmental \\ Science Program \\ Universitas Riau \\ Indonesia
}

*corresponding author: Joleh, 'joleha@eng.unri.ac.id

\begin{abstract}
Rainwater harvesting that is good and right by the needs of household clean water is one of the problems for the people in the islands in Indonesia, especially Merbau Island which is located in the Kepulauan Meranti Regency, Riau Province. The only source of clean water that can be enjoyed easily and cheaply is rainwater. Rainfall on Merbau Island ranges between $2.000-4.000 \mathrm{~mm}$ per year which is classified as moderate. A survey of 100 randomly selected people was conducted, with a questionnaire containing components for rainwater harvesting (RWH) and other core questions. If available rainfall is used optimally, the need for clean water on the island can be met. Calculation of rainwater for cooking, drinking and washing needs is estimated to be around 15 lpcd. The data obtained is rainfall in $\mathbf{2 0 1 6}$ with a total rainfall of $1,754 \mathrm{~mm}$, roof storage area of $36 \mathrm{~m} 2$, and the type of roof used is zinc. Rain cycle $\mathrm{V} 2$ simulation produces a $3 \mathrm{~m} 3$ volume rainwater storage tank, with a construction cost of Rp. $10,365,000$. This tank can meet the needs of clean water for five family members for a year.
\end{abstract}

Keywords - Rainwater Harvesting, Domestic, Sustainable, Supply

\section{INTRODUCTION}

The growing crisis over water has thus focused attention on ways to make use of rainfall and run off [1], making rainwater harvesting projects expected to be as large as possible to reduce difficult situations in the future.

Rainwater harvesting projects are simple and low-cost water supply techniques that involve the capturing and storing of rainwater from roofs and ground catchments for domestic, agricultural, industrial and environmental purposes. Though harvesting of rainwater and runoff has been practised for centuries in different parts of the world, the practice has received little attention until relatively recently [1].

One promising technology to abate water scarcity and flooding is through harvesting rainwater. The variability of rainfall has triggered a myriad of rainwater harvesting schemes which have sprouted in recent years, both in Kenya and in other water-stressed nations with the aim to abate drought and the water shortages [2].

Rainwater harvesting is performed in many regions of the world to capture and store rainwater to meet domestic water needs, i.e. water for drinking and cooking, irrigation [3], stormwater control [4], supplementing municipal water supply in urban areas [5], and assisting in rural and urban water control and management [6]. In many parts of southeast Asia, central China, Africa, the Caribbean, and the Indian and Pacific Ocean, communities depend almost exclusively on the use of household rooftop rainwater catchment system [7].

Also, rainwater is harvested to meet the needs for domestic, industrial, agricultural and environmental use [8 11], toilet flushing, washing, maintaining landscapes and also groundwater [11-12]. Many studies have suggested rainwater as an alternative due to water shortage as the effect of population rise, climate change, and pollution [13]. Some other studies correlated the rainfall and population density to assert optimal tank size [14].

According to Julius et al. [15], rainwater harvesting could be one of the best methods available to restore the natural hydrological cycle and to allow sustainable urban development. Another objective of rainwater harvesting as mentioned by Ojwang et al. [16] is to examine some appropriate and feasible solutions for developing rainwater harvesting (RWH) techniques technically, and economically hence it is affordable for future users based on their hydrological, technical, social and cultural conditions. Bhattacharya [17] also mentions some advantages of rainwater harvesting such as it is simple, cheap, replicable, efficient, sustainable and adaptable, applicable on a small scale, easily operated, highly adaptive and cost-efficient. 
Notwithstanding, the widespread uptake of RWH technology has been slow partly due to the inability of the poor to finance the systems. Consequently, support for the development of RWH has been based on funding from external sources. However, as observed by Cain [18], the overall funding available from NGOs and international finance organizations for DRWH is limited. People are usually willing to build their RWH supply, in part or totally by themselves if suitable financing mechanisms are available [19]. Such financing mechanisms must be sustainable and take into consideration the budgetary constraints of households.

Despite all these efforts, the effects of rainwater harvesting projects on household welfare, food security, and sustainable development have not been assessed and documented. Some of the studies have revealed the role of rainwater in alleviating hunger; however, little has been done to assess the level of adoption of these projects and effects on sustainable human welfare. The lack of tangible evidence on the significance of rainwater harvesting projects in human welfare and sustainable development could be the reason why there have been little efforts from the government and the line ministries in setting up guiding policies on these projects.

Therefore, the purpose of this study was to obtain field data on domestic clean water needs on Merbau Island and rainwater harvest planning data such as roof area, type of roof and number of family members in one household. From this data, the volume of rainwater harvesting tanks is designed, and the costs required. Thus, if this design is implemented properly and correctly with the assumption that rainfall occurs normally every year, then it is certain that daily clean water needs can be met throughout the year.

\section{STUdy OF AREA}

\section{A. Geography and Demographics}

The regency of Meranti Islands consists of nine subdistricts, namely; Tebing Tinggi Barat, Tebing Tinggi, East Tebing Tinggi, Rangsang, Pesisir Pesisir, Barat Rangsang, Merbau, Merbau Island, and Putri Puyu. This research was conducted in the Merbau Island subdistrict which is the expansion of Merbau subdistrict, with the capital city of Semukut village.

The Merbau Island subdistrict consists of eleven villages, namely, Semukut village, Kuala Merbau, Ketapang Bay, Centai, Ketapang Permai, Padang Kamal, Barang Melintang, Ranak Dungun, Tanjung Bunga, Batang Meranti, and Pangkalan Balai. The total area of Merbau Island is $380,40 \mathrm{~km}^{2}$. Geographically, Merbau Island is located at 01002'45.72 "NL and 102031'56.44" EL, as can be seen in Figure 1.

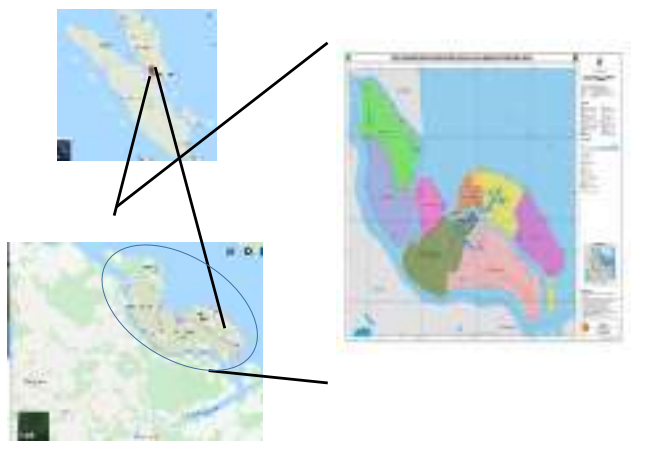

Figure 1: Research sites (modified from Google map and districts profile [20]

\section{B. Topography, weather, and rainfalls}

Topographically, Merbau Island as a part of Meranti Islands Regency is in the eastern coast of Sumatera island which is lowland, relatively flat with the level of land slope ranging from $0-2 \%$, with a height of $5-7$ meters from sea level, mainly consists of peat swamps and lowland swamps. The total area of Meranti Island is $1,348.91 \mathrm{~km}^{2}$, consisting of islands and oceans. Merbau Island has an area of 380.40 $\mathrm{km}^{2}$, which is surrounded by Asam Strait, Air Hitam Strait and Malacca Strait [21]

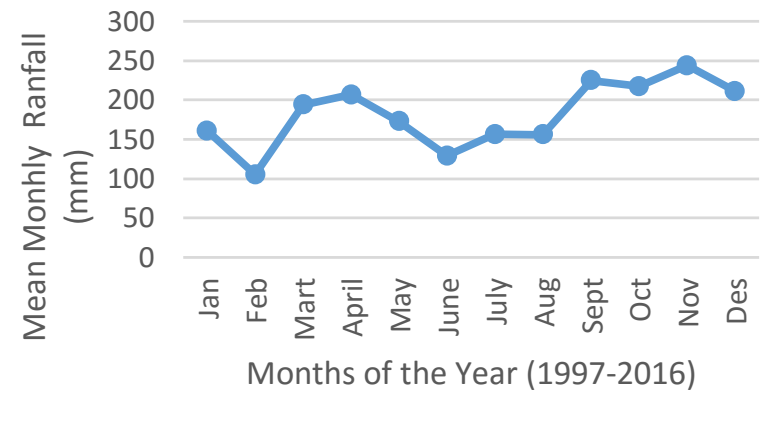

Figure 2: Mean of rainfalls in Meranti Islands regency in 1997-2016

Based on rainfall data, the Regency of Meranti Islands is classified into areas with moderate rainfall $(2.000-4.000$ $\mathrm{mm})$. From 1997 to 2016, the number of rainy days in Meranti Regency totaled 166 rain days in 2003 with the highest rainfall per year at $3.164,3 \mathrm{~mm}$ in the same year [22]. The graph in figure 2 shows the rain pattern in Selat Panjang and surrounding areas

\section{Methodology}

This research is based on the fieldwork carried out on the island of Merbau in 2017. Secondary data on population, climate, rainfall etc. are collected from each department. The availability and type of roof for rainwater collection has been collected from each village on Merbau Island.

The estimated sample of water tank capacity to meet drinking water needs of $15 \mathrm{lpcd}$ from the roof of $36 \mathrm{~m}^{2}$ and 
for five family members has been done using the rain cycle v2 program.

The rainwater harvesting systems at households were observed thoroughly during the visit to eleven villages of Merbau Island. The observation focused mainly on the physical condition of the installed RWH systems, their functioning, and level of service delivery, operation and maintenance aspects of the systems (Fig. 3). This helped validation and cross-check of data gathered from households and the individual interviews.

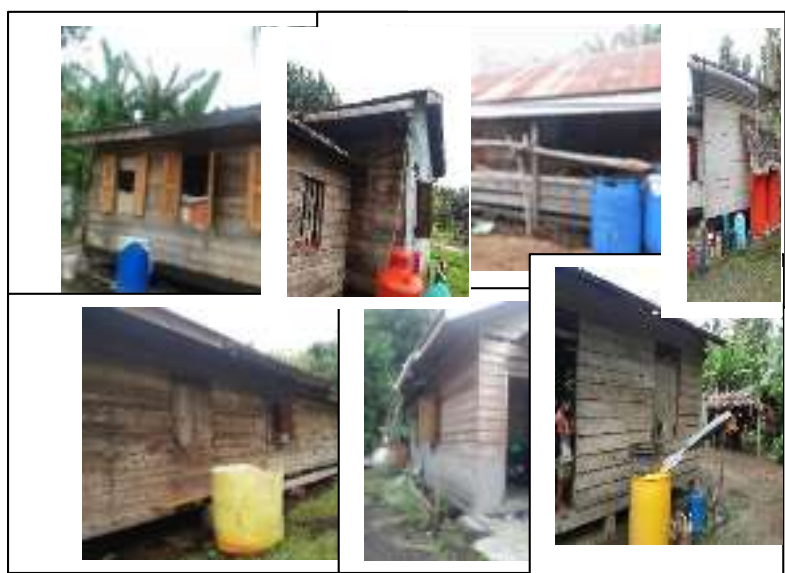

Figure 3: Conventional rainwater harvesting on the island of Merbau

The estimated cost of rainwater harvesting facilities that have been designed is calculated to find out the maximum price spent by each household to be able to meet the $100 \%$ clean water requirement.

\section{RESUlt AND DisCUSSION}

\section{A. Potential of Rooftop Rainwater Harvesting in Merbau Island}

The potential of rainwater harvesting from the roof is normally called annual yield from a given roof area. It is the quantity of water in liters collected from a given roof throughout one year covering all rainy days. It is the product of the roof area and the annual

rainfall. It depends upon the amount of rainfall, the area and the type of roof. The potential of rooftop rainwater harvesting has been calculated by using the following formula [Gould \& Nissen Formula, [23]:

$$
\mathrm{S}=\mathrm{R} \times \mathrm{A} \times \mathrm{Cr}
$$

Where $S=$ Potential for rooftop rainwater harvesting $\left(\mathrm{m}^{3}\right) ; \mathrm{R}=$ Mean annual rainfall in meters; $\mathrm{A}=$ Roof Area in Sq.m and $\mathrm{Cr}=$ Coefficient of run off. The table 1 below shows the coefficient of runoff for various types of roof materials [24].

Table 1: Typical runoff coefficients for various roof types

\begin{tabular}{|l|l|c|}
\hline Surface & Type & Coefficient \\
\hline \multirow{3}{*}{ Roof } & Pitched roof tiles & $0,75-0,90$ \\
\cline { 2 - 3 } & Flat rof with smoot sursce & $0,50-0,60$ \\
\cline { 2 - 3 } & Flat roof wih gravel or thin turf $(<150 \mathrm{~mm})$ & $0,40-0,50$ \\
\hline
\end{tabular}

The size of the family in Merbau Islands varies from two member family to nine and more. Maximum numbers of families' i.e $36 \%$ have 5 to 7 members in their families followed by $25 \%$ have four members in their families (table 2).

Table 2: The size of the family in Merbau Island

\begin{tabular}{|c|c|c|c|}
\hline No & $\begin{array}{c}\text { Size of Family (No. of } \\
\text { persons) }\end{array}$ & $\begin{array}{c}\text { No. of } \\
\text { Houses }\end{array}$ & $\begin{array}{c}\text { Percentage of } \\
\text { Total Houses }\end{array}$ \\
\hline 1 & 2 & 12 & 0,12 \\
\hline 2 & 3 & 12 & 0,12 \\
\hline 3 & 4 & 25 & 0,25 \\
\hline 4 & 5 to 7 & 36 & 0,36 \\
\hline 5 & $8+$ & 15 & 0,15 \\
\hline
\end{tabular}

\section{B. Estimation of Water Tank Capacity}

Mean monthly rainfall data of the study region is used to estimate the monthly roof rainwater harvesting potential by applying Gould and Nissen method.

Domestic water demand from a family (five persons) @ 15 lpcd for each month has been calculated. This ranges from 2.330 lt. to 2.100 lt. per month. The cumulative demand from a family is also calculated to determine the total annual water demand. It came to around 27.380 lt. The graph in figure 4 shows that RWH potential is quite high compared to the cumulative demand for domestic water. The total account potential is RWH for $62.700 \mathrm{lt}$. and the cumulative demand for the total domestic water @ 15 lpcd is 27.380 lt.

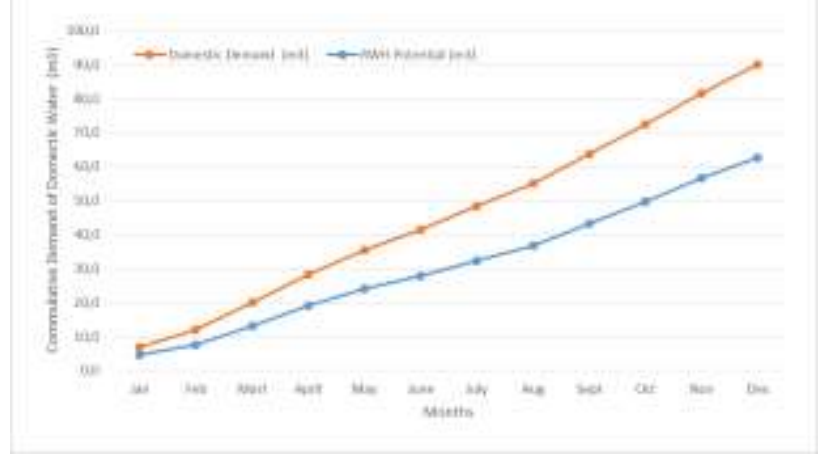

Figure 4: Comparison between Cumulative Water Demand and RWH Potential

This also shows that only 43,67 percent of the potential is sufficient to meet the domestic demand for water @ 15 liters/person/day. The monthly RWH potential ranges from 3.030 lt. up to 7.020 lt. This is the highest for November and the lowest for February.

Rain Cycle V2 simulation has been done to estimate the capacity of the water tank to meet drinking water needs @ 15 lpcd. The data used in the rain cycle is daily rainfall in 2016, the roof area of $36 \mathrm{~m} 2$ with some family members of 5 people, and the type of roof is zinc with a runoff coefficient of 0.80 . Figure 5 is the result of a rain cycle simulation that illustrates that the percentage of rainwater availability for 
family needs is $100 \%$ fulfilled if there is a storage capacity of $3 \mathrm{~m}^{3}$.

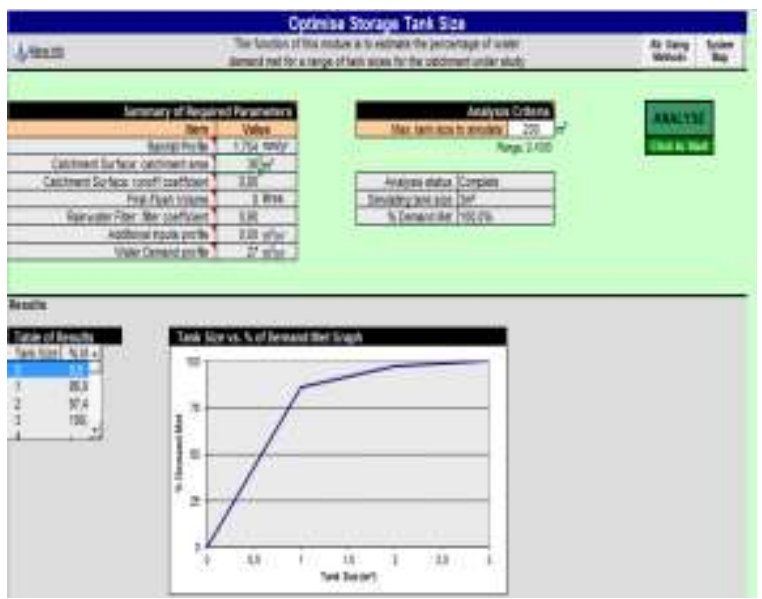

Figure 5: Tank size vs \% meeting household water needs.

In domestic Roof Rainwater Harvesting Systems, rainwater from the house roof is collected in a storage tank to be used for domestic purpose throughout the year. Usually, these systems are designed for drinking, cooking, and washing clothes of a family. Such a system usually comprises a roof, a storage tank, and gutters to transport the water from the roof to the storage tank. In addition to it a first flush diverter also put to prevent the entry of the first monsoon shower in the storage tank. Therefore, a typical rooftop Rainwater Harvesting System (Fig. 6) comprises the following components:

- Roof catchments

- Gutters

- Downpipe

- First, flush chamber

- $\quad$ Storage tank

Among the above components, a storage tank is the most expensive and critical components. The capacity of the storage tank determines the cost of the system. Use of locally available materials reduces the overall cost of the system.

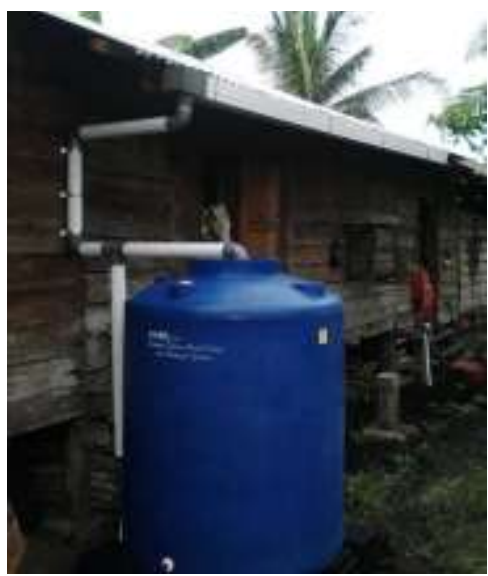

Figure 6: The main component rainwater harvesting system

Cost calculations have been carried out (table 3) to create a rainwater harvesting system to meet the domestic water needs of the Merbau island community with a $36 \mathrm{~m}^{2}$ roof area and some family members of 5 people.

Table 3: Total installation costs (Rp) for plastic tanks $1 \mathrm{~m}^{3}, 2$ $\mathrm{m}^{3}$ and $3 \mathrm{~m}^{3}$ on the roof of $36 \mathrm{~m}^{2}$.

\begin{tabular}{|l|l|r|r|r|}
\hline No. Components & $\mathbf{1}$ tank (Rp) & 2 tanks (Rp) & 3 tanks (Rp) \\
\hline \hline 1. & Tank & 1.650 .000 & 3.300 .000 & 4.950 .000 \\
\hline 2. & Tank transport & 300.000 & 600.000 & 900.000 \\
\hline 3. & Pipes & 150.000 & 175.000 & 225.000 \\
\hline 4. & Elbow & 100.000 & 120.000 & 145.000 \\
\hline 5. & Tap & 15.000 & 30.000 & 45.000 \\
\hline 6. & Gutter & 200.000 & 200.000 & 200.000 \\
\hline 7. & Tank holder & 800.000 & 1.600 .000 & 2.400 .000 \\
\hline 8. & Labour & 500.000 & 1.000 .000 & 1.500 .000 \\
\hline \multicolumn{2}{|r|}{ Total } & $\mathbf{3 . 7 1 5 . 0 0 0}$ & $\mathbf{7 . 0 2 5 . 0 0 0}$ & $\mathbf{1 0 . 3 6 5 . 0 0 0}$ \\
\hline
\end{tabular}

The total installation cost is around Rp. 10,365,000 for a $3 \mathrm{~m}^{3}$ tank. This fee is around $36 \%$ of the annual minimum income. These costs can also be reduced if they ignore labor costs. To reduce the large initial costs, adding the number of tanks can be done in stages.

In addition, $44.4 \%$ of the population of Merbau Island is poor (Fig. 7), making it difficult to fulfill RWH facilities optimally. Therefore, so that RWH can be implemented to the fullest, there needs to be government intervention in the construction of clean water needs facilities on Merbau Island.

The factor of poverty is very dominant affecting the people's purchasing power towards the provision of clean water storage facilities on Merbau Island. This can be shown in Figure 8 that the average water storage facility owned by the community that exceeds $1 \mathrm{~m} 3$ (1000 liters) is only 15\% of the total number of respondents, and $59 \%$ of the community has more than $0.5 \mathrm{~m} 3$ of storage, and $19 \%$ of people who do not have rainwater storage tanks.

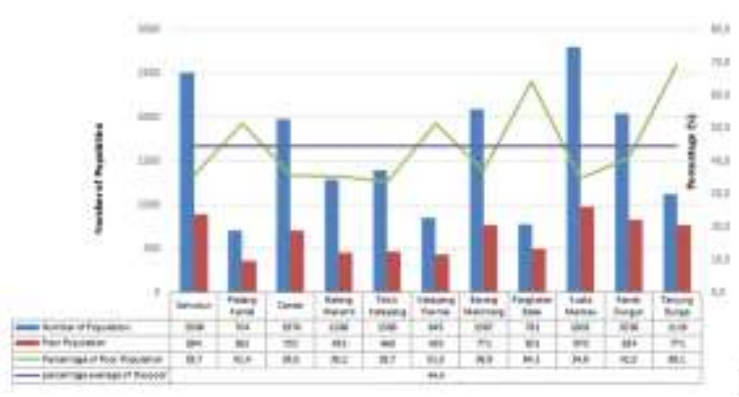

Figure 7: The number of population in comparison to the number of poor population in Merbau island subdistrict in 2015

The government issued a policy listed in Government Regulation No. 16 of 2005 concerning raw water for household drinking water, from now on referred to as raw water, is water originating from surface water, groundwater and rainwater sources that meet raw water quality standards for drinking. Law Number 7 of 2004 concerning Water Resources states that the state guarantees the right of everyone to get water for basic needs to fulfill their lives that are healthy, clean and productive. Water resources are 
controlled by the state and are used to the maximum extent possible for the people's prosperity.

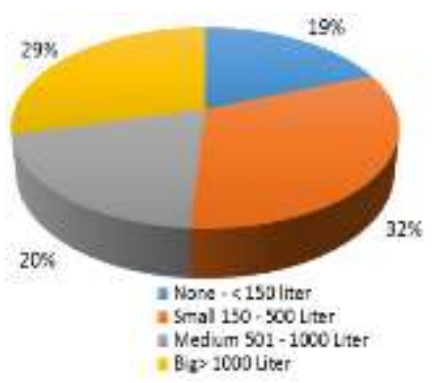

Figure 8: The rainwater container used by Merbau Island people

Therefore, the government's efforts and attention play an important role in meeting clean water needs on Merbau Island. The government is considered to have budget availability in an effort to succeed in managing water resources because the government is a budget organizer that has an obligation to protect and empower the community for the welfare of society.

\section{CONCLUSION}

Merbau Island, which does not have an adequate source of clean water, can use rainwater sources as clean water. Rainfall that occurs throughout the year can overcome the scarcity of clean water on the island of Merbau by harvesting rainwater. The available rainfall is able to meet the needs of clean water for eating, drinking and washing clothes which is equivalent to $15 \mathrm{lpcd}$.

A tank of $3 \mathrm{~m}^{3}$ is needed to meet $100 \%$ of the clean water needs of the people of Merbau Island with a roof area of 36 $\mathrm{m}^{2}$ in a house that has a number of family members of 5 people. To provide rainwater harvesting installations, the community needs to pay Rp.10,365,000 .

\section{ACKNOWLEDGMENT}

The author would like to thank the promoter team for their commitment, constant support, encouragement and tutoring throughout the execution of this research.

\section{REFERENCES}

[1] Ngigi, S.N, "Rain water harvesting for Improved Food Security", Promoting Technologies in the Greater Horn of Africa. Greater Horn of Africa Rainwater Partnership (GHARP). Kenya Rainwater Association (KRA), 2003.

[2] Aroka, N, "Rainwater Harvesting in Rural Kenya: Reliability in a variable and changing climate", Msc thesis, Departement of Physical Geography and Quaternary Geology, Stochholm University, 2010.
[3] Jones, M. P., \& Hunt, W. F, "Performance of rainwater harvesting systems in the southeastern United States. Resources", Conservation and Recycling, 54(10), 623-629, 2010.

[4] Burns, M. J., Fletcher, T. D., Walsh, C. J., Ladson, A. R., \& Hatt, B. E, "Hydrologic shortcomings of conventional urban stormwater management and opportunities for reform", Landscape and Urban Planning, 105(3), 230-240, 2012.

[5] Steffen, J., Jensen, M., Pomeroy, C.A., and S.J. Burian, "Water supply and stormwater management benefits of residential rainwater harvesting in U.S", cities. J. Amer. Water Res. Assoc, 49(4), 810-824, 2013.

[6] Ward, S., Memon, F. A., \& Butler, D, "Performance of a large building rainwater harvesting system", Water research, 46(16), 51275134,2012

[7] Opare, S, "Rainwater harvesting: an option for sustainable rural water supply in Ghana", GeoJournal 77:695-705, 2012.

[8] Che-Ani A.I, Shaari N, A. Sairi, M.F.M. Zain, M.M. Tahir. (2009). Rainwater Harvesting as an Alternative Water Supply in the Future, European Journal of Scientific Research ISSN 1450-216X. Vol.34 No.1.pp.132-140.

[9] Ngigi, S.N, "Optimization of Rainwater Catchment Systems Design Parameters in the Arid and Semiarid Lands of Kenya", Department of Agricultural Engineering University of Nairobi. Nairobi, Kenya, 2003.

[10] Thomas, T, "Domestic water supply using rainwater Harvesting. Building Research \& Information", 26(2), 94-10, 2010.

[11] An, KJ. Lam, YF. Hao, S. Morakinyo, TE. \& Furumai, H, "Multipurpose rainwater harvesting for water resource recovery and the cooling effect", Watres xxx, 1- 6, 2015.

[12] Edgar L.V., Andrew, D, "Analysis of a rainwater collection system for domestic water supply in Ringdansen", Norrkoping, Sweden, Building and Environment 40 (9), pp. 174-1184, 2005.

[13] Dagnachew, A,. Marina, B.J,. Brook, L. Geremew, S.G, "Assessing the Potential for Rooftop Rainwater Harvesting from Large Public Institutions", Int. J. Environ. Res. Public Health. 15, 336, 2018

[14] Shubham, J. Pankaj, T. Siddharth, S. Mehul, S, "Design of Rooftop Rainwater Harvesting Tank for Katpadi Region", Tamil Nadu, SSRG International Journal of Civil Engineering (SSRG-IJCE), volume 2 Issue 7, 2015

[15] Julius, J.R. Angeline, P. Ravikumar, G, "Rainwater Harvesting (Rwh) - A Review", International Journal of Scientific \& Engineering Research, Volume 4, Issue 8, 2013.

[16] Ojwang, R.O,. Dietrich, J,. Anebagilu, P.K.. Beyer, M. Rottensteiner. F, "Rooftop Rainwater Harvesting for Mombasa: Scenario Development with Image Classification and Water Resources Simulation", Water, 9, 359, 2017.

[17] Bhattacharya, S, "Traditional water harvesting structures and sustainable water management in India: A socio-hydrological review", International Letters of Natural Sciences, Vol. 37, pp. 30-38, 2015.

[18] Cain, N.L, "A different Path: The global water crisis and Rainwater Hatvesting", Consilience: The Journal of Sustainable Develompment, 12(1), 147-157, 2014.

[19] Hartung, H., \& Rwabambari, C, "Financing mechanisms for roofwater harvesting, An example from Uganda", 13th International Rainwater Catchment Systems Conference Rainwater and Urban Design, Sydney, Australia, 2007.

[20] Profil Pulau Merbau, Kecamatan Pulau Merbau, 2015.

[21] http://www.ppk-kp3k.kkp.go.id/direktoripulau/index.php/public_c/pulau_info/ 382\#gu, 2017.

[22] BWSS III, Data Curah Hujan Stasiun Dumai, 2017.

[23] Gould, J. and Nissen-Petersen, E, "Rainwater Catchment Systems for Domestic Supply", International Technology Publications, London, United Kingdom, 1999

[24] Roebuck, R, "Raincycle Standar(c) V2. Rainwater Harvesting Hydraulic Simlation \& Whole Life Costing Tool", www.SUDSoutions.com, 2015. 